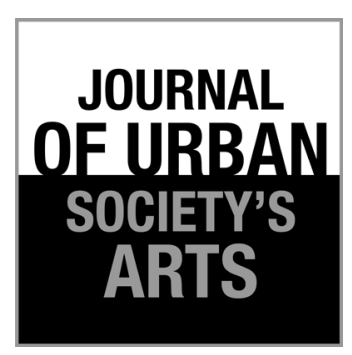

Volume 4 Nomor 1, April 2017: 49-60

\section{Fotografi adalah Seni: Sanggahan terhadap Analisis Roger Scruton Mengenai Keabsahan Nilai Seni dari Sebuah Foto}

\author{
Andreas Arie Susanto
}

Program Studi Magister Ilmu Teologi, Universitas Katolik Parahyangan

Jln. Ciumbuleuit No.94, Hegarmanah, Cidadap, Bandung, 40141

Tlp.081276254379,E-mail: goddiie7@gmail.com

\begin{abstract}
ABSTRAK
Tulisan ini bertujuan untuk menyanggah argumentasi Roger Scruton mengenai keabsahan nilai seni dari sebuah foto. Scruton berpendapat bahwa fotografi bukanlah karya seni. Fotografi hanyalah sebuah tindakan mekanis dalam menghasilkan suatu gambar, bukan representasi melainkan hanyalah peristiwa kausal, bukan gambaran imajinasi, tetapi hanya kopian. Fotografi mengandaikan adanya kemudahan dalam penciptaan seni. Pernyataan Scruton semakin dikuatkan dengan fenomena perkembangan teknologi yang sudah melupakan sisi estetis dan hanya berpasrah sepenuhnya pada tindakan mesin. Penekanan berlebihan terhadap keunggulan reduplikasi, proses instan, dan otomatisasi fotografi membuat fotografi kehilangan tempatnya di dunia seni. Akan tetapi, persoalan seni adalah persoalan rasa. Fotografi tetaplah sebuah seni dengan melihat adanya relasi intensional yang tercipta antara objek dan seorang fotografer dalam sebuah foto. Relasi intensional ini tercermin dalam proses, imajinasi, dan kreativitas fotografer di dalam menghasilkan sebuah foto. Lukisan dan fotografi adalah seni menurut rasanya masing-masing.
\end{abstract}

Kata kunci: Roger Scruton; seni fotografi; estetika fotografi

\begin{abstract}
Photography is an Art: A Disaproval towards Roger Scruton's Analysis on the Legitimacy of Art Value of a Photograph. This paper aims to disprove Roger Scruton's argument about the validity of the artistic value of a photograph. Scruton argues that photography is not a work of art. Photography is simply a mechanical action in producing a picture, not a representation but merely a causal event, not an imaginary image, but only a copy. Photography presupposes the ease of art creation. Scruton's statement is further reinforced by the phenomenon of technological development that has forgotten the aesthetic side and only entirely devoted to the action of the machine. The excessive emphasis on the benefits of reduplication, instant processing, and photographic automation makes photography lose its place in the art world. However, the issue of art is a matter of taste. Photography remains an art by seeing the intense relationships created between an object and a photographer in a photograph. This intense relationship is reflected in the process, imagination, and creativity of the photographer in producing a photograph. Painting and photography are arts according to their own taste.
\end{abstract}

Keywords: Roger Scruton; art of photography; aesthetics of photography 
(Sumardjo, 2000: 135). Sementara itu, teknologi tercipta sebagai perpanjangan tubuh manusia. Teknologi digunakan untuk mengatasi banyak kesulitan manusia dalam menghadapi dunianya. Kedua hal inilah yang membedakan manusia dari makhluk hidup lainnya. Seorang filsuf Prancis, Jean Baudrillard mengatakan bahwa keduanya merupakan perpanjangan imajinasi yang mampu merealisasikan fantasi-fantasi manusia (Hartanto, 2013: 2). Sebagai salah satu wujud perpanjangan imajinasi manusia inilah lahir fotografi, sebuah perpaduan unik antara teknologi dan seni.

Fotografi sudah sangat akrab dalam kehidupan saat ini, bahkan tidak berlebihan jika dikatakan fotografi sudah menjelma sebagai sebuah ikon, zeitgeist atau roh zaman, atau dapat disebut sebagai sebuah gaya hidup baru dalam masyarakat (Rony, 2014). Zaman yang serba cepat dan instan membuat setiap manusia mau tidak mau menjadi larut di dalamnya. Waktu berubah dan cara manusia dalam mengekspresikan diri, mencari makna dirinya dan orang lain juga ikut berubah (Mudji \& Putranto, 2005: 7). Gaya hidup "berfoto", kiranya sebutan ini cukup menggambarkan fenomena yang terjadi pada zaman ini. Fotografi menjadi salah satu media visual yang memberi daya tarik sendiri bagi manusia zaman sekarang. Pembuktian secara sederhana dapat ditemukan di sekeliling. Di setiap tempat, waktu, dan kesempatan dapat dengan mudah ditemukan orang yang membawa kamera baik kamera profesional maupun hanya sekadar kamera yang ada dalam telepon seluler dan berkemampuan seadanya. Setiap orang seakan tidak ingin kehilangan momen dalam hidupnya, segala bentuk rupa keindahan dengan cepat ditangkap dan diabadikan. Kemudahan dan kecepatan yang ditawarkan oleh fotografi membuat seseorang seakan menjadi seniman karbitan. Fenomena di sekitar ini menjadi perhatian dalam dunia fotografi yang akhirnya menimbulkan sebuah pertanyaan mendasar yang sangat berkaitan dengan estetika dan konsep keindahan, "Apakah fotografi masih dapat disebut sebagai seni?"

Perkembangan fotografi ke arah digital membuat pertanyaan tersebut menjadi relevan. Pemilihan objek foto yang asal, proses yang instan, kemudahan dalam mencipta dan menghapus hasil foto semakin mencerminkan tidak bergantungnya lagi fotografi pada karsa sebagai manusia. Setiap orang dapat dengan mudah mengambil foto dan tidak memerlukan syarat khusus seperti halnya seorang pelukis ketika akan memulai melukis di atas kanvas. Fotografi seakan menjurus pada proses mekanistis. Seperti yang dikatakan Walter Benjamin, fotografi membebaskan tangan sebagai fungsi artistik yang paling penting, dan menggantikannya dengan sebuah mata yang melihat pada sebuah lensa (Benjamin, 1999: 213). Kenyataan ini sekilas mereduksi fotografi sebagai sebuah seni. Yang dilihat secara dominan bukan lagi unsur seni dalam sebuah foto, melainkan jatuh pada sisi mekanis fotografi dalam menghasilkan suatu imaji, gambaran dari realitas.

Perkembangan teknologi sepertinya memunculkan permasalahan serius bagi keberadaan seni. Teknologi seakan mengeliminasi "aura" dari seni. Reproduksi mekanis yang merupakan produk perkembangan teknologi, diklaim memberi pengaruh buruk bagi perkembangan seni. Muncul dualisme, yakni di satu sisi, area kerja fotografi adalah sebagai seni visual yang berkaitan dengan keindahan, membangkitkan perasaan dan melibatkan kreativitas. Di sisi lain, fotografi merupakan suatu proses reduplikasi, reproduksi secara instan menggunakan mesin. Dualisme ini yang selalu membingungkan dalam ranah fotografi.

\section{Roger Scruton Menilai Fotografi}

Ambiguitas dalam diri fotografi ini juga diamini oleh seorang filsuf bernama Roger Vernon Scruton. Scruton mengajar sebagai dosen dan profesor estetika di Birkbeck College, London. Sepak terjangnya dalam dunia filsafat dan estetika sudah amat dikenal oleh para ahli. Ia adalah seorang filsuf yang memiliki spesialisasi dalam bidang estetika khususnya pada musik dan arsitektur. Scruton juga termasuk salah satu dari empat pendiri Conservative Philosophy Group, yang bertujuan untuk memelihara pengetahuanpengetahuan konservatif.

Scruton lahir pada 27 Februari 1944 di Buslingthorpe, Lincolnshire, Inggris. Semasa muda, ia mengikuti kelas di Royal Grammar School High 
Wycombe (1954 - 1961). Ia lalu meninggalkan sekolah tersebut karena mendapatkan beasiswa untuk bersekolah di Universitas Cambridge. Di tempat itu Scruton mempelajari moral science, yang pada zaman sekarang lebih dikenal dengan nama jurusan filsafat, dan lulus pada tahun 1965. Ia lalu menyelesaikan jenjang Master pada tahun 1967. Akhirnya pada tahun 1972 dia menyempurnakan tesis doktoralnya dalam bidang estetik. Setelah mendapatkan gelar master, Scruton mengajar di Universitas Birkbeck, London dari tahun 1971 sampai dengan tahun 1992. Ia dikenal sebagai dosen dan profesor ternama di bidang estetika. Kini ia menetap di Inggris, tepatnya di Wiltshire dan masih aktif mengajar di beberapa universitas. Dalam perjalanan hidupnya, ia telah menulis 30 buku, di antaranya Art and Imagination (1974), The Meaning of Conservatism (1980), Sexual Desire (1986), The Philosopher on Dover Beach (1990), The Aesthetics of Music (1997), The Aesthetic Understanding (1998) dan Beauty (2009).

Scruton tidak hanya melihat sisi mekanistis dari fotografi, tetapi juga memperlihatkan kelemahan mendasar fotografi jika ingin disebut seni melalui perbandingan dengan lukisan. Bagi Scruton, lukisan adalah suatu bentuk seni yang sempurna. Baginya, lukisan penuh dengan intensionalitas dari seorang pelukis yang merupakan syarat dari sebuah representasi (Costello \& Philips, 2008: 5). Ketika seorang apresiator melihat sebuah lukisan, ia akan dapat melihat suatu yang baru tanpa harus diyakinkan dengan melihat objek yang dilukis terlebih dahulu. Lukisan dapat menghadirkan sebuah relasi visual antara subjek dan lukisan (Scruton, 1998: 120). Sang pelukis menghadirkan cara pandang (way of seeing) dari subjek yang ada dalam lukisan.

Walaupun fotografi dapat dikatakan sempurna dalam merepresentasikan gambaran sebuah benda, fotografi bukanlah sebuah seni representasi. Hal ini ia sampaikan secara terperinci dalam esainya yang bertajuk "Photography and Representation". Ia melihat bahwa ada suatu masalah dalam kesesuaian dan keakuratan fotografi. Scruton menekankan pentingnya memisahkan lukisan dan fotografi secara lebih dalam. Tidak melihat pada lukisan atau fotografi yang aktual (yang sebenarnya), namun menitikberatkan pada bentuk ideal dari keduanya (Scruton, 1998: 119). Sebuah ideal yang memunculkan perbedaan esensial antara mereka. Fotografi ideal berbeda dari fotografi aktual seperti halnya lukisan ideal berbeda dari sebuah lukisan aktual. Aktual fotografi adalah hasil dari usaha yang dilakukan oleh seorang fotografer untuk mencemari ideal dari karya mereka dengan tujuan dan metode-metode lukisan.

Konsep “ideal” dimaksudkan Scruton sebagai sebuah logika ideal. Sebuah ideal dari fotografi adalah menjadi tidak ideal lagi ketika fotografi bertujuan atau harus memiliki tujuan. Sebaliknya, jika itu terjadi maka fotografi adalah sebuah logika khayalan, fiksi, yang sengaja dirancang hanya untuk menangkap apa yang istimewa dalam relasi fotografi dan kehendak di dalamnya. Sebuah ideal bagi lukisan membiarkan orang yang melihat sebuah lukisan untuk mengenali subjek yang ada dalam lukisan sejauh gambaran yang digambarkan seorang seniman sebagai sebuah realisasi intensinya. Hal ini dikarenakan adanya ekspresi pemikiran di dalam sebuah lukisan. Konsep ideal sebuah lukisan berbeda dengan konsep ideal fotografi, orang yang melihat hasil foto dapat mengenali yang ada di foto tersebut hanya sejauh apa yang ditampilkan oleh foto tersebut, tidak lebih.

Lukisan ideal berada dalam sebuah relasi intensional khusus pada subjeknya (Scruton, 1998: 120). Dengan kata lain, jika sebuah lukisan merepresentasikan sebuah subjek, tidak langsung diikuti dengan subjek tersebut ada atau tidak. Jika tidak ada, lukisan merepresentasikan subjek tersebut seperti adanya. Lebih jelasnya, jika $X$ adalah sebuah lukisan dari seorang pria, tidak langsung mengindikasikan bahwa ada orang yang khusus digambarkan sebagai $X$ dalam lukisan tersebut. Selanjutnya, sebuah lukisan berada dalam relasi intensional pada subjeknya dikarenakan sebuah tindakan representasional, tindakan dari sang seniman, dan dalam melukiskan hubungan antara sebuah lukisan dan subjeknya, juga dapat melihat intensi dari seniman itu sendiri. Realisasi yang berhasil dari intensi tersebut terdapat dalam penyusunan penampilan atau bentuk dari lukisan.

Fotografi ideal bagi Scruton, juga memiliki relasi khusus dengan subjek yakni sebuah foto 
adalah sebuah foto dari suatu benda. Akan tetapi, relasi yang tercipta adalah relasi kausal bukan relasi intensional seperti dalam lukisan. Dengan kata lain, jika sebuah foto adalah sebuah foto atau cerminan dari subjek, mengatakan bahwa subjek tersebut ada. Jika $X$ adalah sebuah foto dari seorang pria, ada seorang pria khusus yang mewakili gambaran $X$ dalam foto tersebut. Subjek tersebut langsung dapat dikenali dengan melihat apa yang muncul pada sebuah foto. Yang terjadi bukanlah sebuah proses intensional, melainkan proses kausal. Fotografi ideal juga menghasilkan sebuah foto, namun foto tersebut tidaklah semenarik seperti halnya realisasi dari sebuah intense, tetapi hanya sebagai sebuah rekaman dari objek secara sebenarnya. Bagi Scruton, konsep fotografi ideal berada pada sebuah relasi kausal pada subjeknya dan menampilkan subjeknya dengan meniru penampilannya. Dengan meniru sebuah penampilan, sebuah objek mirip seperti halnya terlihat pada manusia dengan mata biasa, walaupun dengan menggunakan sudut pandang tertentu.

Untuk mendukung pernyataan itu, Scruton memberikan beberapa premis, yakni pertama, subjek dari sebuah fotografi ideal pasti ada. Kedua, wujud atau tampilan dari kira-kira sama dengan apa yang terlihat dalam sebuah foto. Ketiga, penampakan subjek pada sebuah foto adalah penampakannya pada sebuah momen tertentu dalam situasi tertentu (Scruton, 1998: 125). Premis pertama adalah fakta bahwa relasi antara sebuah foto dengan subjeknya adalah sebuah relasi kausal. Fotografi langsung menunjuk pada benda yang dipotret, dan apresiator tidak dapat melihat hal lain di dalamnya, khususnya seperti intensi si pelukis ketika membuat lukisan. Fotografi ideal tidak mampu untuk merepresentasikan suatu benda yang tidak nyata, abstrak. Dalam hal ini fotografi berperan "indexis" atau menunjukkan (Friday, 2002: 69). Kamera digunakan bukan untuk merepresentasikan sesuatu, melainkan untuk menunjuk langsung padanya. Hanya berhenti pada tanda dan tidak mencapai pada level simbolisme. Karakter dari simbolisme adalah komunikasi dalam level relasi intensional seperti yang terjadi dalam lukisan. Premis kedua, subjek dalam fotografi ideal harus tampak kurang lebih sama seperti yang terlihat dalam sebuah foto. Secara alamiah, fotografi hanya dapat "merepresentasikan" suatu kemiripan. Fotografi hanya berperan sebagai sebuah pengingat secara visual dari suatu subjek, namun kita tergoda untuk mengatakannya sebagai representasi dari si subjek. Berkaitan dengan ini, sesuai dengan premis ketiga, sangat tidak mungkin mengatakan bahwa hal tersebut adalah suatu representasi jika yang terlihat dalam foto hanya memperlihatkan subjek itu secara riil. Fotografi memperlihatkan, menampilkan subjek seperti bagaimana kelihatannya. Fotografi hanya memberikan sesuatu untuk dilihat dan bukan memberitahu bagaimana untuk melihatnya (way of seeing).

Bagi Scruton, ketiga hal tersebut menjadi sangat penting dan setidaknya menyadarkan dalam mengapresiasi segala macam efek yang terjadi dalam sebuah foto. Dengan melihat pada fotografi ideal, dapat disadari bahwa melihat sesuatu yang sedang berlangsung dan melihatnya sebagaimana kelihatannya. Foto bersifat sangat transparan pada subjeknya, sebagai penghubung pada apa yang terlihat dalam foto tersebut. Dengan demikian, ketika ada orang yang mengatakan bahwa sebuah foto itu indah, hal tersebut dikarenakan orang tersebut menemukan suatu yang indah pada subjeknya. Melihat foto pegunungan itu indah karena pada dasarnya pegunungan itu indah.

Berbeda dengan lukisan, sebuah lukisan dapat saja dikatakan indah, walaupun ia menampilkan suatu hal yang buruk atau jelek (Scruton, 1998: 134). Sebuah lukisan dari Andrea Mantegna di Louvre, Crucifixion, dapat membangkitkan ketenangan, ketenteraman, meskipun secara gamblang yang terlukis di atas kanvas adalah gambaran kemartiran, kematian di salib yang normalnya menghadirkan kesan horor dan menakutkan (Gambar 1). Lukisan mempunyai kualitas emosional yang bisa saja berbeda dengan kualitas emosional subjeknya (Scruton, 1998: 152). Dalam fotografi, katakanlah suatu foto yang menampilkan korban kecelakaan, maka sikap seseorang ditentukan oleh pengetahuan dalam dirinya mengenai gambar tersebut. Foto tersebut menarik pengetahuan untuk mengidentifikasi foto tersebut sebagai hal yang naas dan menyedihkan. 
Sekali lagi, sikap yang keluar saat memandang foto tersebut mencerminkan relasi kausal antara fotografi dengan apa yang ada di dalam foto.

Imaji yang ditampilkan dalam foto sangat tergantung pada subjeknya dan bukan pada intensi sang fotografer. Foto dikatakan menyentuh karena si subjeklah yang menyentuh. Bukan karena intensi fotografer yang membuat foto itu menjadi menyentuh. Segala sesuatu tergantung subjek. Transparansi imaji menjadi jiwa dalam fotografi. Transparansi dari fotografi ini menjadi sebuah hal esensial bagi realisme dunia fotografi. Realisme fotografi berbeda dengan realisme dalam lukisan. Seperti halnya melihat melalui cermin, gelas, dan juga kaca, yang terlihat adalah objek tersebut bukan yang lain. Hal ini tidak terjadi pada lukisan karena dalam lukisan, apa yang terlihat dimediasikan oleh pemikiran sang pelukis dan bukan proses mekanisasi. Ketika seorang pelukis dihadapkan pada sebuah area kosong pada kanvas, ia akan membanjirinya dengan produk produk hasil olahan imajinasi (Adams, 1994: 145). Sementara itu, fotografi butuh ada subjek yang menjadi objek foto demi mengisi kanvas kosongnya. Hasil foto tidak lebih dari sebuah kopian dari realitas, menampilkan apa adanya, identik dengan subjek yang difoto dan terlalu realistis untuk sebuah karya seni. Ketika melihat suatu foto yang di dalamnya ada kita, tidak mungkin dapat berkilah bahwa itu bukan kita, hal ini sudah menjadi bukti nyata. Bahkan

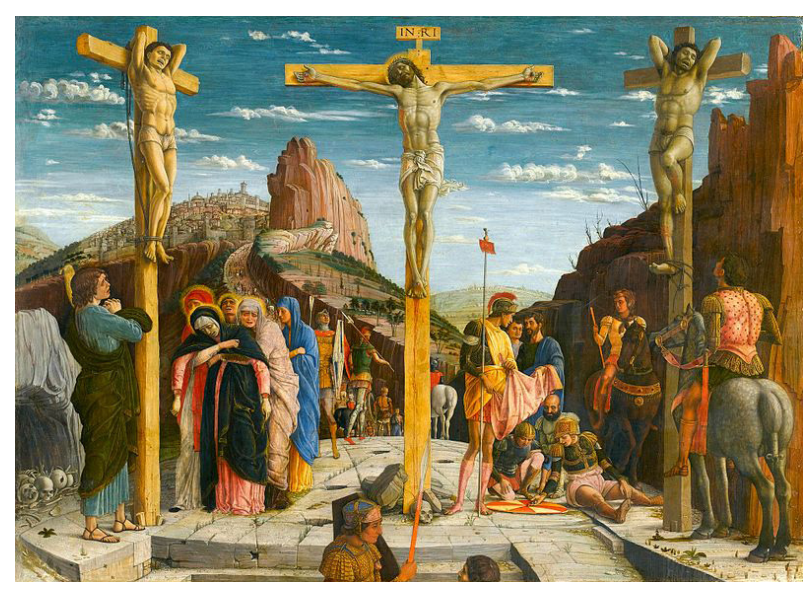

Gambar 1. Sebuah lukisan dari Andrea Mantegna di Louvre, Crucifixion (Sumber: https://en.wikipedia.org/ wiki/Crucifixion_(Mantegna)\#/media/File:Mantegna,_ Andrea_-_crucifixion_-_Louvre_from_Predella_San_ Zeno_Altarpiece_Verona.jpg, diakses pada Jumat, 24 Februari 2017, pukul. 12.30 WIB). oleh fotografer perempuan pertama, Anna Atkins (1799-1871), fotografi diklaim sebagai tampilan sempurna sama seperti objeknya (Johnson, 1989: $10)$.

Dalam esainya, Scruton terlihat mempertahankan argumen-argumennya dengan menampilkan kemungkinan-kemungkinan keberatan yang akan diajukan oleh pihak yang tidak menyetujui pernyataannya. Fotografi bukanlah sebuah seni representasi. Tidak mungkin ada rasa atau nilai estetis di dalamnya karena foto hanya menampilkan apa yang ada di foto tersebut dan tidak memasukkan unsur estetis di dalamnya. Meskipun sebuah foto mengklaim dirinya adalah foto seni, hal tersebut tetaplah sebuah foto dan bukan sebagai sebuah pekerjaan seni (Costello \& Philips, 2008: 4). Pendapat Scruton mengenai fotografi bukanlah seni sejajar dengan perkataan Benjamin dalam The Work of Art in The Age of Mechanical Reproduction bahwa fotografi mencoba menyentuh wilayah kerja seni namun kualitas kehadirannya akan menjadi susut (Benjamin, 1999: 215). Dalam hal ini seni menjadi kehilangan dalam keunikannya, sebab dalam era reproduksi mekanikal, segala pekerjaan seni dapat direproduksi dan dapat digandakan sehingga nilai seni menjadi susut. Dalam The Death of Art, Arthur Danto juga mengkritik banyaknya benda yang mengklaim diri seni padahal hanya sekadar kitsch, hal ini menjadikan seni kehilangan sentuhan dan batasannya menjadi tidak jelas.

\section{Otomatisasi dalam Fotografi}

Proses fotografi dapat disebut sebagai sebuah otomatisasi, foto yang dihasilkan merupakan hasil kinerja dari sebuah mesin yang disebut kamera. Otomatis dan instan, tidak diperlukan waktu lama untuk menghasilkan sebuah foto. Hanya perlu satu jari dari si fotografer untuk menekan tombol maka sebuah foto akan tercipta. Roger Scruton juga menyebutkan mengenai hal ini dengan mengatakan fotografi bukanlah sebuah proses intensional, melainkan suatu proses permainan optik kimiawi semata. Intensi fotografer tidak terlalu berperan dalam fotografi, hanya memindahkan realitas ke dalam foto yang ia hasilkan. Hal ini juga diungkapkan oleh Stanley Cavell bahwa fotografi 
adalah sebuah proses otomatisasi, menyingkirkan unsur subjektif dari representasi gambar. Secara tidak langsung proses otomatisasi meminggirkan manusia dari proses penciptaan sebuah gambar itu sendiri (Stanley, 1979: 20). Otomatisasi memiliki kaitan dengan mekanisasi. Prinsip kerja otomatis, instan merupakan imbas dari perkembangan teknologi. Seperti halnya dikatakan oleh Charles Baudelaire, bahwa perkembangan teknologi membuat manusia tidak perlu terlalu terlatih, cukup hanya dengan mengikuti cara kerja dari mesin, otomatis (automaton) (Benjamin, 1999: 172).

Patrick Maynard, mengatakan bahwa penggunaan teknologi dalam penciptaan gambar dapat membantu memperluas ataupun memberi batasan pada kemampuan untuk mengidentifikasi sesuatu dan untuk membayangkannya (Maynard, 1997: 113). Dengan adanya teknologi, tentu saja dapat memudahkan, dan pada saat yang sama sekaligus melemahkan. Dengan menggunakan kamera seseorang dapat dengan mudah memberhentikan waktu, menangkap sesuatu hingga membuatnya frozen in time (Ajidarma, 2007: 1). Dengan keotomatisan fotografi ini, lagi-lagi timbul keraguan terhadap posisi fotografi dalam dunia seni.

\section{Menilik Fotografi sebagai Sebuah Seni}

Fotografi berasal dari kata Yunani, yakni "phos" yang artinya cahaya dan "graphe" yang artinya melukis (Sugiharto, 2013: 122). Fotografi dapat diartikan sebagai sebuah cara melukis dengan menggunakan media cahaya. Fotografi seakan mampu menggantikan peran lukisan sebagai sebuah seni representasi karena hasil yang dihasilkan kamera saat itu mirip atau menyerupai lukisan. Dengan melihat pengertian dan awal perkembangan fotografi, terlihat bahwa fotografi berusaha masuk dalam kategori seni visual yang mampu merepresentasikan keindahan secara sempurna bak sebuah lukisan. Jika kita melihat perkembangan fotografi dari masa ke masa, dari awal camera obscura - cahaya yang diproyeksikan melalui sebuah lubang kecil sehingga membuat pola-pola yang bervariasi pada suatu permukaan
(Peres, 2007: 27), hingga kamera yang dikenal di zaman ini, membuat sadar bahwa tidak ada suatu yang instan, para ahli selalu berusaha agar kamera menjadi lebih baik dari waktu ke waktu. Usaha ini demi suatu cita-cita mendapatkan gambar yang indah melebihi yang mampu ditangkap oleh mata manusia.

Di awal keberadaan fotografi, fotografi bisa saja diragukan dalam ranah seni sebab melihat dari alat dan bahan yang digunakan serta intensi di balik perkembangan fotografi tidaklah bermuatan seni, tetapi hanya sekadar reduplikasi. Penggunaan mesin dan perkembangan teknologi menjadi sebuah hal utama dalam pengembangan hasil fotografi hari demi hari, intensi yang dikembangkan pun hanya semata bisa menyempurnakan pengambilan realitas secara akurat dan transparan dalam sebuah gambar. Jika fotografi hanya dilihat berdasarkan alat bernama kamera, hanya akan disebut otomatisasi dan mekanisasi. Skeptisisme Scruton terhadap fotografi bisa jadi beralasan jika dilihat dalam konteks zaman awal perkembangan fotografi. Akan tetapi, jika ingin menilik lebih dalam terhadap fotografi akan ditemukan unsur seni yang tertuang di dalamnya.

\section{Konsep Representasi Fotografi}

Scruton mengatakan bahwa sangatlah tidak mungkin untuk mendapatkan sebuah ketertarikan estetis dari suatu foto sebab relasi yang tercipta dalam foto adalah relasi kausal dan bukan sebuah relasi intensional seperti dalam sebuah lukisan. Hubungan kausal dalam fotografi tidak dapat dipungkiri sudah mendarah daging dalam foto. Akan tetapi, seorang fotografer mempunyai banyak kesempatan untuk memanipulasi, mengontrol efek dari relasi kausal tersebut (Jonathan, 2002: 72). Intensionalitas dari fotografer membuatnya mampu memilih dan menggunakan teknik serta material yang akan digunakan dalam mengambil sebuah foto. Perkembangan fotografi ke arah digital membuat penciptaan sebuah representasi menjadi mungkin. Pada awal perkembangan fotografi, konsep kausalitas dan nonrepresentasi sangat terlihat dalam foto-foto yang dihasilkan. Foto-foto pada masa awal tersebut bersifat dokumenter dan 
langsung menunjuk pada objek yang difoto. Setelah melalui masa fotografi digital, foto-foto menjadi lebih kreatif dan tidak hanya sekadar memindahkan realitas.

Tanggapan mengenai konsep representasi juga datang dari David Bate, bahwa ada hal lain yang mampu disampaikan oleh sebuah gambar (David, 2009: 30). Sebuah gambar tidak hanya langsung menunjuk pada objeknya, namun dapat juga merepresentasikan hal lain. Sebagai contoh, foto seekor sapi yang sedang memakan rumput terlihat sehat dan bergembira. Dalam hal ini, foto tidak saja berarti ingin menampilkan seekor sapi yang sedang makan rumput, sehat dan gembira. Akan tetapi, foto ini juga merepresentasikan sebuah makna bahwa segala yang dihasilkan dari sapi tersebut berkualitas baik. Dapat dilihat secara langsung pada kemasan susu, terpampang foto dari sapi sehat tersebut sehingga orang menjadi tertarik dan percaya untuk membelinya. Hal ini adalah contoh dari representasi dalam sebuah foto.

Di sisi lain, fotografi memberikan sesuatu yang lebih leluasa dari yang bisa diberikan oleh mata. Pendapat ini datang dari Joel Snyder dan Neil Walsh Allen, sebuah foto memperlihatkan sebuah objek pada momen tertentu dalam waktu (Levinson, 2003: 618). Kedua orang ini menggunakan peran interpretasi yang dilakukan fotografer dalam pembuatan sebuah foto. Kamera memang menunjukkan objek yang ingin dipotret, tetapi fotografer mampu untuk memilih objek yang akan dipotret, serta cara memotretnya, yang nantinya akan merepresentasikan pemikiran fotografer.

\section{Kompleksitas Sebuah Foto}

Dalam penilaian sebuah karya seni, ada suatu unsur yang tidak pernah terlepaskan, yakni perihal kompleksitas dalam karya seni tersebut. Karya seni yang terlampau sederhana terkadang dianggap kurang menyampaikan nilai seni di dalamnya. Jika Scruton acap kali membandingkan fotografi dengan sebuah lukisan, berikut sisi kompleksitas sebuah lukisan dan fotografi. Kompleksitas terlihat dalam fresco-fresco yang tercipta pada zaman Gothic, lukisan Picasso dan juga Seurat.
Dalam hal ini, fotografi juga dapat menampilkan kompleksitas tersebut dalam sebuah foto. Foto tidak hanya menjadi sekadar kopian realitas, namun menjadi lebih bercerita dengan adanya permainan sudut pandang, permainan cahaya, komposisi dalam sebuah gambar dan juga berkaitan dengan permainan warna di dalamnya (Kusrini, 2016). Kompleksitas ini menampilkan sebuah objek dalam foto tidaklah lagi dapat bersifat indexis, melainkan lebih bersifat seni. Dalam sebuah pandangan populer, kamera adalah sejenis visi otomatis yang dapat merekam sesuatu, tetapi membutuhkan makhluk yang kreatif untuk membawanya pada seni (Bate, 2009: 27). Untuk membuat sebuah foto menjadi kompleks dibutuhkan peran kreatifitas dari sang fotografer. Hal ini menandakan bahwa fotografi tidaklah sekadar cerminan realitas semata jika ditambah unsur kreativitas sang fotografer di dalamnya.

\section{Foto Mengundang Refleksi}

Barbara Savedoff pernah menekankan mengenai kekuatan transformatif dari sebuah foto (Levinson, 2003: 623). Melalui foto, subjek ditransformasikan dalam berbagai cara sehingga tidak mudah jika langsung menyebutkannya sebagai sebuah rekaman atau suatu yang bersifat dokumenter. Mengacu pada pandangan Scruton yang mengatakan bahwa foto memperlihatkan objek sebagaimana adanya, foto dari bunga tidak lantas langsung mengacu hanya pada bunga tersebut, tetapi ada banyak cara pandang untuk melihat foto bunga tersebut. Intensi dari fotografer bermain di dalamnya.

Eugene Atget, seorang fotografer Prancis, menuliskan "Dokumentasi untuk Seniman" di depan studio fotonya di Paris (Ajidarma, 2007: 5). Judul itu ia tulis sebagai pengantar bahwa di dalam studio fotonya terdapat 10.00 lempengan negatif yang merekam segenap sudut kota Paris, semuanya dalam keadaan lengang tanpa manusia. Untuk apa ia melakukan ini? Atget ingin mencoba mengumpulkan gambar sebagai bentuk reproduksi dari hal-hal yang biasa terlihat (Adams, 1994: 123). Ia mengumpulkan gambar dari berbagai sudut kota Paris, dari kehidupan normal, pagi hari menjelang 
segala kesibukan orang bekerja, hingga kehidupan di luar normal, pembunuhan, perampokan, rumahrumah bordil, para pekerja seks, dan juga pengemis. Semua ia kumpulkan untuk melihat sisi lain dari Paris seperti yang banyak orang tahu. Baginya, gambar berbicara banyak saat kata-kata tidak mampu mengungkapkannya. Foto-fotonya ini mengundang refleksi dari para apresiator untuk melihat representasi dari kota Paris. Dalam hal ini ada suatu proses penyingkapan yang terjadi, bahwa seseorang yang melihat foto-foto ini mampu untuk melihat makna di baliknya (beyond). Orang terserap di dalam foto-foto tersebut dan menjadi masuk ke dalam foto, menyentuh wilayah rasa. Memberi kesan yang lebih daripada apa yang kelihatan.

\section{Foto yang Mempunyai Intensi}

Seni memang merupakan kegiatan memproduksi efek inderawi, imajinatif, dan rasawi (Sugiharto, 2013: 35). Dalam memproduksi efek inderawi, imajinatif, dan rasawi tersebut diperlukan intensi dari fotografer dalam proses fotografi. Keinginan, maksud awal, dan tujuan yang disebut intensi ini harus ada di dalam kepala fotografer dalam proses menciptakan sebuah gambar. Dalam hal ini sebuah foto harus menampilkan sebuah momen sehingga dapat memberikan sebuah pesan dan tidak hanya sekadar menampilkan hubungan kausal. Melalui gambar-gambarnya, Henri Cartier Bresson selalu memberikan jembatan antara realis dan idealis, memberikan suatu perspektif unik

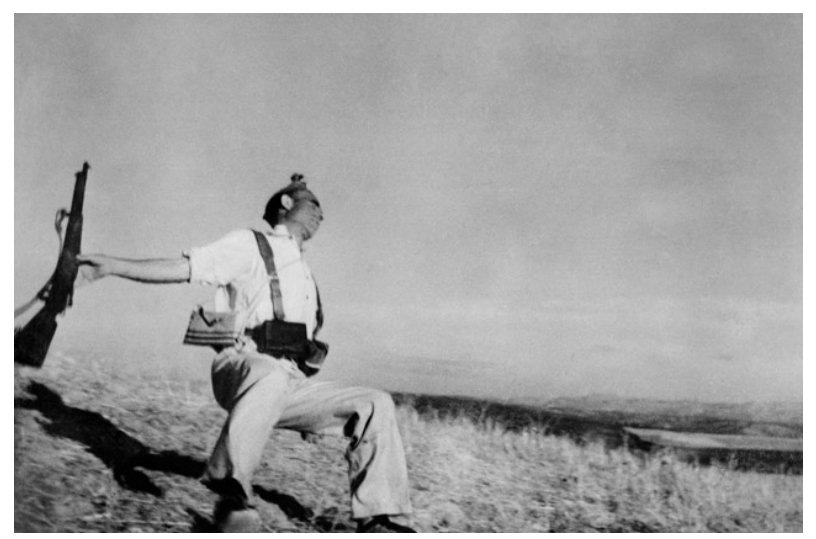

Gambar 2. Foto hasil karya Robert Capa: Matinya Seorang Serdadu Loyalis (Sumber: http://a.abcnews. com/images/International/HT_robert_capa_2_ nt_131022.jpg _ diakses pada Minggu, 26 Februari 2017, pukul 13.23 WIB.) dalam fotografi, mengubah suatu yang banal menjadi suatu yang spesial dan tidak terbayangkan (Friday, 2002: 125).

Mata seorang fotografer secara terusmenerus selalu mengevaluasi (Ajidarma, 2007: 60). Suatu gambar diambil tidaklah bersifat serta merta. Butuh momen yang tepat dalam mengambil sebuah foto, sampai-sampai tiap jam memberikan sentuhan yang berbeda dalam gambar yang dihasilkan. Seorang fotografer yang ingin mengambil foto perlu memperhitungkan "decisive moment" ala Bresson. Sebagai contoh, ketika akan mengambil foto dari perempuan cantik yang sedang berjalan di antara orang banyak. Ia perlu sabar untuk menunggu gadis cantik itu tepat lewat di hadapannya dan tidak tertutup oleh orang-orang yang sedang berjalan di sekitarnya dan membentuk komposisi yang menarik sebagai permainan dari intuisi. Saat menunggu ia pun terus mengukur rasa dalam hal menekan tombol rana untuk mengambil gambar. Ketika gambar jadi, momen inilah yang akan berbicara, dan mustahil jika seseorang ingin mengambil obyek yang sama lagi akan menghasilkan gambar atau foto yang sama pula. Sebagai contoh ia memakai foto dari Robert Capa: Matinya Seorang Serdadu Loyalis (Gambar 2). Kamera Capa tepat berbunyi ' $k$ lik' pada saat sebutir peluru menghantam kepala serdadu tersebut. Melalui gambar tersebut, terlihat momen sungguh menentukan bagaimana gambar diciptakan. Mustahil jika Scruton mengatakan gambar ini sebagai kopian dari objeknya langsung. Memang kopian objek, namun momen objek tersebut tidaklah dapat mengacu pada keadaan riil objek. Dalam foto ini bukan objek yang terlihat, melainkan persoalan waktu dan momen di dalamnya sehingga mampu menggambarkan representasi intensi dari fotografer akan foto tersebut. Di sinilah foto dikatakan memiliki sebuah relasi intensional dan tidak lagi sekadar kausal.

\section{Way of Seeing dalam Fotografi}

Scruton menitikberatkan fotografi dalam sebuah foto dalam sebuah hasil. Bahwa sebuah foto menunjuk langsung pada objek yang berada di dalam foto, sebuah objek foto mengacu secara 
langsung pada objek secara riil, bersifat transparan. Tidak ada representasi dalam sebuah foto. Semua ini menandakan bahwa Scruton mengacu pada "what" yang paling primer. Akan tetapi, jika ingin melihat di balik foto tersebut dapat ditemukan halhal yang paling primer, yakni "who" dan "why". Bukan lagi mengenai gambar yang dihasilkan, melainkan siapa yang menghasilkan gambar tersebut dan apa yang mendasarinya menciptakan gambar tersebut. Seorang seniman harus menjadi orang yang jenius sebab seni adalah hasil pemikiran filosofis dan metafisis, bukan hanya sekadar pemindahan realitas. Estetis juga memiliki artian berbobot filosofis.

Mengacu pada pandangan Scruton, apakah seorang fotografer tidak dapat mencapai level filosofis saat dirinya mempunyai alasan yang kuat untuk merepresentasikan sesuatu yang dianggap metafisis? Jika ia dapat mencapainya, tidaklah berlebihan jika kita dapat mengatakan bahwa fotografi adalah seni.

\section{Merefleksikan Nilai Seni dari Fotografi}

Semenjak kemunculan fotografi, para seniman lukis merasa hal itu adalah pertanda kematian dari seni lukis sebab fotografi dapat dengan mudah meniru realitas dan mencetaknya dalam sebuah kanvas. Fotografi dapat menyajikan suatu gambaran dengan begitu akurat dan cepat, suatu hal yang tidak ada dalam diri lukisan. Akan tetapi, kekuatan yang ada dalam diri fotografi ini membuatnya dipertanyakan dalam dunia seni. Pada dasarnya lukisan dan fotografi bergerak dalam bidang yang sama, yakni bidang visual. Sebuah bentuk, hasil karya manusia yang dapat ditangkap melalui mata manusia.

Pada abad 19, untuk dapat menentukan nilai artistik dari lukisan dan fotografi sangatlah membingungkan. Semua memiliki nilai artistik sesuai dengan zamannya masing-masing. Sebelum ditemukannya fotografi, khususnya di wilayah Barat, memiliki pemahaman bahwa seni adalah lukisan (Adams, 1994: 7) dan belum ada tempat bagi fotografi. Akan tetapi, pada era mekanikal seperti saat ini, harus mampu melihat peran seni dalam perkembangan kultur (Walter, 1999: 220).
Walter Benjamin melihat bahwa "aura" seni saat ini ialah proses mekanistis dan reproduksi yang amat lekat dengan fotografi. Foto adalah suatu pesan yang dibentuk dari pemindahan objek nyata ke dalam sebuah gambar. Sebuah imaji dapat berbicara banyak tanpa harus disertai teks, hal inilah yang terjadi dalam fotografi. Dalam penciptaan gambar perlu ada intensi aktif di dalamnya. Intensi ini berada dalam keduanya, yakni dalam lukisan dan juga sebuah foto. Adanya peleburan identitas di dalamnya, penghayatan secara total, hingga akhirnya mencapai tahap tersingkapnya aspek-aspek baru dalam kenyataan (Sugiharto, 2013: 37).

Sesuai pendapat Scruton, bahwa dalam sebuah foto hasil dari kegiatan fotografi tidaklah pernah dapat dianggap sebagai suatu representasi, bagaimana mungkin fotografi dapat mengklaim diri sebagai seni jika hanya menampilkan benda dalam foto sama seperti aslinya. Transparan, tidak ada intensi dan tidak ada representasi di dalamnya. Akan tetapi, hal itu tidak sepenuhnya benar. Seno Gumira Ajidarma mengungkapkan sebuah contoh sebuah foto yang berjudul Batu, apakah foto tersebut sekadar representasi sebuah batu entah di mana? Batu itu barangkali memang sebuah batu yang ada di pojok rumah, bisa saja di pelosok terpencil dan mungkin bisa saja hanya kebetulan sang fotografer melihatnya lalu memotretnya. Kemudian ketika dipamerkan foto tersebut mendapatkan bermacam-macam tanggapan, dari aspek teknis (pori-pori batu yang terlihat jelas), aspek artistik (komposisinya bagus), maupun dari aspek substansinya. Dalam situasi seperti ini, batu dan Batu sudah terikat untuk saling menunjuk, Batu tidak harus selalu dilihat sebagai representasi batu karena pembermaknaannya termungkinkan menunjuk ke arah lain, tidak selalu kepada batu yang dipotret. Sebuah dunia telah tergandakan. Foto Batu memang bisa diasalkan pada batu yang dipotretnya, namun foto Batu itu sanggup dan mampu dan memang merupakan sebuah dunia baru di luar batu yang dipotretnya (Ajidarma, 2007: 142).

Dalam konsep pemikiran Barat, seni visual mengacu pada lukisan, dan sudah berakar selama berabad-abad. Dengan demikian, tidak gampang 
jika menyebutkan seni adalah fotografi sebab keberadaan fotografi masih prematur dan oleh beberapa ahli seni masih dianggap sebagai suatu "benda asing" dalam dunia seni (Taminiaux, 1994: 7). Akan tetapi, fotografi tetap dapat tampil sebagai sebuah seni, secara konkret sebagai seni pada era perkembangan teknologi. Penting diingat bahwa fotografi tidaklah serta merta berkaitan dengan hasil, tetapi sebuah proses untuk sampai pada hasil tersebut. Dalam artian inilah fotografi senantiasa dikatakan sebagai sebuah seni.

\section{Simpulan}

Fotografi adalah suatu bentuk terluas dari media visual. Fotografi juga adalah suatu bentuk bahasa universal yang dapat dimengerti dan dinikmati oleh setiap orang. Fotografi merupakan ekstensifikasi dari mata manusia dalam menangkap keindahan. Kemunculan fotografi pun membawa polemik yang membingungkan para apresiator dan pencinta seni, untuk menggolongkannya dalam sebuah seni ataupun bukan. Hal ini dirasa sebagai suatu yang wajar sebab selama berabad-abad lukisanlah yang dianggap layak untuk memakai kata 'seni' khususnya dalam ranah media visual. Perbincangan mengenai posisi fotografi dalam dunia seni pun ternyata sudah menjadi hal yang selalu diperdebatkan dari dulu hingga sekarang.

Kausalitas fotografi mengacu pada kesamaan objek dalam sebuah foto dengan objek secara riil. Fotografi hanyalah seperti sebuah cermin. Ketika suatu objek dihadapkan padanya maka yang terlihat pasti objek tersebut, bukan yang lain. Dengan kata lain yang ada dalam sebuah foto adalah realitas itu sendiri, bersifat transparan dan langsung menunjuk benda yang ada dalam foto tersebut, sedangkan dalam lukisan secara ideal disajikan konsep representasi yang sempurna. Dalam hal menyajikan sebuah gambar atau imaji, lukisan memberikan cerminan dari pemikiran sang pelukis di balik lukisan tersebut. Intensi pelukis tergambar dalam lukisan yang digambarnya, para apresiator seni dapat melihat lukisan sebagai representasi pemikiran sang seniman lukis.

Pernyataan Scruton meliputi empat hal, yakni pertama, sebuah objek dapat diklaim sebagai seni visual hanya jika ia adalah sebuah representasi. Kedua, sebuah imaji dapat disebut representasi hanya jika imaji tersebut merepresentasikan pemikiran atau perasaan dari sang seniman mengenai objek yang ditampilkan. Ketiga, ekspresi tersebut difasilitasi oleh pengontrolan seniman terhadap imaji tersebut, dan orang yang melihatnya tetap melihat foto yang dihasilkan sebagai subjek itu sendiri dan bukan representasi. Keempat, dalam proses fotografi, seniman tidaklah terlalu berperan (mekanisasi) sehingga imaji yang dihasilkan bukanlah merupakan sebuah representasi dan tidak dapat dikatakan sebagai suatu perkerjaan seni (Kusrini, 2015). Perkataan Scruton ini tidaklah berdiri sendiri, beberapa ahli dalam bidang seni, estetika bahkan filsafat pun mengumandangkan beberapa hal yang memberatkan posisi fotografi dalam dunia seni. Dilihat dari sisi teknis, pengambilan foto tentu saja bersifat mekanistis. Memilih objek yang akan difoto, kemudian menekan tombol dan hanya membiarkan optik dan mesin yang bekerja hingga tercipta sebuah gambar. Kemudian melihat hasil foto yang hanya sekedar reduplikasi dari realitas, meniru realitas secara sempurna, kesempurnaannya inilah yang menjadi sebuah keberatan untuk menggolongkannya sebagai sebuah seni.

Budaya massif zaman sekarang membuat banyak orang seakan mendukung pernyataan Scruton. Pengagungan yang berlebihan terhadap teknologi seakan sudah menjadi roh permanen zaman ini. Tidak lagi menjadi penting persoalan kemampuan (skill), tetapi yang menjadi penting adalah "mempunyai" (having). Dengan demikian, manusia menjadi bergantung sepenuhnya pada mesin dan menjadi miskin dalam hal kreativitas dan imajinasi. Fotografi menjadi sebuah tindakan kausalitas semata seperti apa yang diungkapkan Scruton. Fotografi menghentikan kerja tangan seperti halnya dalam melukis dan menggantikannya dengan sebuah mata untuk melihat melalui sebuah lensa.

Unsur transparansi dalam diri fotografi membuat posisinya dalam dunia seni seakan terjun bebas dan tidak ada bedanya dengan sekedar kitsch. Sekilas, dan didukung oleh realita zaman sekarang, pernyataan Scruton dapat dikatakan benar. Akan 
tetapi, apakah benar di dalam sebuah foto, hanya akan terlihat objek itu sendiri dan tidak ada sedikit pun representasi, imajinasi ataupun konsep intensi fotografer di dalamnya? Jawabannya tentu tidak. Dalam sebuah foto pasti terlihat suatu hal yang baru dan mengarah pada keindahan. Dalam sebuah foto pula orang dapat diajak untuk masuk ke dalam foto tersebut dan menyelami intensi fotografer. Fotografi tetaplah berada dalam wilayah seni. Ia mempunyai kekuatan tersendiri dengan keakuratan dan sifat transparan yang ia miliki, namun dengan tetap melibatkan imajinasi dan kreativitas. Perkembangan konsep seni senantiasa berubah sesuai zamannya, pada zaman dahulu, lukisanlah yang memegang peran sebagai sebuah seni. Akan tetapi, seiring berjalannya waktu fotografi tetap dapat disebut sebagai seni dengan melihat segala intensi dan hal yang berada di balik penciptaan sebuah foto.

Ketika teknologi reproduksi seni ditemukan dalam fotografi, di sana mulai berkembang pula lingkaran-lingkaran pemahaman apresiatif seni fotografi lewat pengembangan dunia mata. Yang perlu menjadi perhatian adalah dikotomi antara apresiasi terhadap buah karya seni dan teknik mesin penggarapnya. Ketika orang menomorsatukan kinerja mesin lebih daripada karya seni itu sendiri lalu yang berkembang adalah teknik dari fotografi yang pada titik ekstrem melupakan bahwa hal tersebut adalah suatu proses estetika.

Jika mendukung bahwa fotografi tetap dianggap sebagai sebuah seni, dalam proses mengambil gambar harus senantiasa menyertakan unsur kreativitas dan imajinasi di dalamnya. Dengan demikian, foto yang dihasilkan tidak hanya sekadar hasil proses mekanisasi dari kamera semata, namun juga merupakan sebuah hasil kolaborasi antara kamera dengan pemikiran sebagai manusia yang penuh intensi, imajinasi, dan kreativitas. Mengeksplor keindahan dari suatu objek yang belum tentu mampu tertangkap jika hanya diamati dengan menggunakan mata telanjang. Lebih mementingkan kualitas yang ada dalam diri sang fotografer dibandingkan mengejar kesempurnaan dalam hal penggunaan kamera serta lensa yang begitu powerful. Seperti halnya ungkapan zaman dahulu, yakni man behind the gun. Yang penting bukanlah alatnya, melainkan orang yang berada di balik alat tersebut. Ungkapan ini menekankan bahwa fotografi bukanlah sekadar reduplikasi imaji secara mekanis, melainkan ada unsur subjektivitas serta intensionalitas fotografer dalam proses fotografis. Perkembangan teknologi harus digunakan dengan lebih baik dan menunjang proses fotografi. Dalam fotografi, seni dan teknologi yang awalnya orang berpikir saling bertolak belakang, berusaha dipadukan dan menghasilkan karya seni baru yang tidak disangka sebelumnya, awalnya saling melemahkan justru saat ini dalam fotografi, seni dan teknologi saling melengkapi.

Kelemahan dalam pendapat Scruton adalah ia tidak melihat pada proses penciptaan sebuah imaji melainkan langsung pada hasil foto yang tentu saja terlihat transparan. Di satu sisi, Scruton kurang tepat dalam membandingkan fotografi dengan lukisan. Lukisan adalah sebuah seni dalam dunianya tersendiri, sedangkan fotografi juga adalah seni dengan keistimewaannya tersendiri. Tidaklah dapat dengan mudah dikatakan bahwa seni merangkai bunga bukanlah dianggap sebagai seni, karena tidak seperti melukis. Seperti halnya apel tidaklah dapat dibandingkan dengan kelapa meskipun keduanya sama-sama buah. Foto dilihat sebagai sebuah seni dengan cara pandang bahwa foto adalah interpretasi dari kenyataan bukan sebuah representasi kenyataan. Semua memiliki ciri khas masing-masing. Secara konseptual, fotografi adalah cara menghasilkan karya visual dengan menggunakan cahaya, tetapi sejauh mana bisa memberi nilai lebih pada foto yang dihasilkan itulah seni fotografi.

\section{Ucapan Terima Kasih}

Penulis sampaikan terima kasih kepada Tuhan Yang Mahabaik atas segala rahmat yang diberikan sehingga dapat membagikan hasil pikiran melalui tulisan di jurnal ini, para pakar yang telah berpartisipasi sebagai mitra bebestari untuk dapat membantu me-review artikel penulis untuk JUSA, Dewan Redaksi JUSA, kedua orang tua penulis atas dukungan moral dan materialnya, dan Bagian Tata Usaha Kampus Teologi Universitas Katolik Parahyangan. 


\section{Kepustakaan}

Adams, R. (1994). Why People Photograph. New York: Aperture Foundation.

Ajidarma, S. G. (2007). Kisah Mata: Fotografi antara Dua Subyek: Perbincangan tentang Ada. Yogyakarta: Galangpress.

Bate, D. (2009). Photography: The Key Concepts. USA: Berg Oxford International Publisher.

Benjamin, W. (1999). Illuminations. London: Pimlico.

Cavell, S. (1979). The World Viewed. England: Harvard University Press.

Costello, D., \& Philips, D. M. (2008). Automatism, Causality and Realism: Foundational Problems in the Philosophy of Photography. Philosophy Compass, 5.

Friday, J. (2002). Aesthetics and Photography. England: Ashgate Publishing Limited.

Hartanto, B. (2013). Dunia Pasca Manusia. Depok: Penerbit Kepik.

Johnson, B. (1989). Photography Speaks. Norfolk: The Chrysler Museum.

Kusrini. (2015). Protret Diri Digital Dalam Seni dan Budaya Visual. Journal of Urban Society's
Arts, 2(2), 111. https://doi.org/10.24821

Kusrini. (2016). Fotografi Jalanan: Membingkai Kota dalam Cerita. Journal of Urban Society's Arts, 3(2), 101. https://doi.org/10.24821

Levinson, J. (2003). The Oxford Handbook of Aesthetics. New York: Oxford University Press.

Maynard, P. (1997). The Engine of Visualization: Thinking through Photography. London: Cornell University Press.

Peres, M. R. (2007). Focal Encyclopedia of Photography. USA: Focal Press.

Rony. (2014). Ikonografi Arsitektur dan Interior Masjid Kristal Khadija Yogyakarta. Journal of Urban Society's Arts, 1(2), 121. https://doi. org/10.24821

Scruton, R. (1998). The Aesthetic Understanding. USA: St. Augustine Press.

Sugiharto, B. (2013). Untuk Apa Seni? Bandung: Matahari.

Sumardjo, J. (2000). Filsafat Seni. Bandung: Penerbit ITB.

Sutrisno, M., \& Putranto, H. (2005). Teori-teori Kebudayaan. Yogyakarta: Kanisius.

Taminiaux, P. (1994). The Paradox of Photography. New York: Rodopi B. V. 